\title{
Historical View of Maghnia Speech Community
}

\author{
Hanane Rabahi 1,2 \\ ${ }^{1}$ Tlemcen University, Tlemcen, Algeria \\ ${ }^{2}$ Mustapha Stambouli University of Mascara, Mascara, Algeria \\ Email: hanane.rabahi@gmail.com
}

Received 29 February 2016; accepted 15 April 2016; published 18 April 2016

Copyright (C) 2016 by author and Scientific Research Publishing Inc.

This work is licensed under the Creative Commons Attribution International License (CC BY).

http://creativecommons.org/licenses/by/4.0/

c) (i) Open Access

\begin{abstract}
This article is to shed some light on the socio-cultural and linguistic profiles of Maghnia speech community and that this homogeneous society has a shared linguistic system and norms, although the use of language differs depending on certain social parameters including gender, age and the educational background. In other terms, Maghnia speakers share the same religious principles, language and history. Maghnia speech community in particular has been influenced by many social and political factors throughout its history. The main factor which makes this society different is its geographical location and contact with Morocco.
\end{abstract}

\section{Keywords}

\section{Gender, Language, Speech Community}

\section{Introduction}

Maghnia $^{1}$ is a town located in North Western Algeria with a population of 8500 inhabitants. It is about 39 km from Tlemcen, $137 \mathrm{~km}$ South-West of Oran and $580 \mathrm{~km}$ West of Algiers. Besides, this town has borders with Morocco. This fact makes it an important for economic, political and cultural contact.

Furthermore, the history of this town is very rich since it witnesses the arrival of many people. In fact, Maghnia was occupied by its indigenous inhabitants in addition to many invaders including Quartzite, Basalt and the Greek. However, the first people who arrived were the Phoenicians and then the Romans who established a station called "Numerus Syrorum" ${ }^{2}$ or "SYR". They also established a military camp, surrounded by a wide and

\footnotetext{
${ }^{1}$ It was the Arabs who gave the name Lalla Maghnia for Maghnia. This name refers to a woman who was worshiping in the area. She was buried near Maghnia. In this place is still today Kouba. This Kouba was built in the late eighteenth century.

${ }^{2}$ The name "numerus syronum" refers to the auxiliary unit of the Roman army which had its garrison in the camp.
} 
deep ditch and flanked by square towers. These towers contained four doors.

Additionally, the history of Maghnia witnessed the arrival of the Muslims who settled with the indigenous tribes. Indeed, it became an important place for settlement especially of the Roman inhabitants who were Arabised after Islamisation. Those people got in contact with the Berbers who were living in the mountains and who formed one-fifth of the total population. But, the indigenous people (Berbers) took the nomadic habits of the Arabs. Henceforth, Maghnia became an important area for economic and commercial exchange.

In 1836, the French expedition came to Tlemcen. Lalla Maghnia was reported to the French officers. In 1843, it was colonized by the general Beadle. During the French period, the city was named Maghnia and was a part of the department of Tlemcen, but after independence, it was, again, renamed Maghnia.

As far as language is concerned, Maghnia people use Modern Standard Arabic in formal domains such as education and Maghnia dialect in informal setting such as family conversation. In fact, this dialect is the result of the contact with the Arabs and the indigenous people (Berbers) Today Maghnia dialect has changed due to the contact with Moroccan varieties. Besides, it has also borrowed from the French language. What can be also observed is that Maghnia speakers have developed a rich vocabulary due to the commercial contact that appears recently.

Keeping this in focus, it may be consumed that this vocabulary is considered as a type of slang which is developed by a specific group of people for commercial purposes. However, this coded language has become a part of daily speech communication used by even teenagers and children. It can be said that this secret language has developed its vocabulary, but what can be noticed is that it is deeply influenced by both Moroccan and Algerian socio-cultural backgrounds. Another important point is that it also takes from Spanish language some expressions mainly "La ballena esta manana la misma musica" (we will exchange goods in the morning in the harbor as we did before).

What can be emphasised, at this point, is that Maghnia dialect is the result of the contact between Arabic and other languages. This fact proves that this dialect has been influenced by variety of socio-cultural backgrounds. Arriving at this fact, it should be also important to say that Maghnia speakers have created a new vocabulary which gives birth to a new dialect.

\section{The Socio-Cultural Background of Maghnia Speech Community}

It is essential to note that the cultural structure of a given speech community determines the position of both males and females. In other terms, there is a belief that the place of women is at home as housewives taking care after children, that is, women are culturally and socially determined. In this sense, Bassiouney (2009: p. 133) cites Sadiqi's point of view as follows:

Sadiqi [...] alludes to the fact that it is not helpful to look at Moroccan women as one entity, since diversity within Morroccan society is essential for a clear understanding of women's position in society.

Additionally, the attitudes of both males and females towards certain linguistic varieties are also influenced by the cultural structure of the society. For instance, women are more conscious in using language in Algeria, i.e. they are aware that the social norms of the Algerian society govern their acts.

Furthermore, Algerian women are socialised from childhood to be polite and conservative. This fact leads Algerian women to use more prestigious forms of speech including French. Besides, it is very rare, in our society, to hear women swearing or using offensive language.

Interestingly, one should mention that some linguistic forms are seen as aspects of femininity such as the use of the glottal stop [?] in Tlemcen dialect, In fact the glottal is seen as a stereotype characterising this variety. Therefore, Tlemcen males avoid it when they are talking to speakers from other towns. This view is better explained through some examples from Maghnia speech community as Table 1 shows.

In addition to this, Algerian males try to show their superiority over females, whereas women struggle to prove their presence. This view is supported by Tannen (1990: pp. 24-25), in her investigation when she claims that men "[...] struggle to preserve independence and avoid failure”, whereas, she adds, women "[...] struggle to preserve intimacy and avoid isolation, though there hierarchies in this world too, they are hierarchies more of friendship than of power and accomplishment”.

\section{Research Methodology}

\subsection{Participants}

The sample of this study is classified into four subcategories, 100 respondents have been given the questionnaire 
Table 1. Gender differences in language use in maghnia speech community.

\begin{tabular}{|c|c|c|}
\hline Terms in English & Males & Females \\
\hline Money & [lbəzra] or [tiki] & [dra:həm] \\
\hline New & [mfamSa] & [3di:da] \\
\hline Drug & [kəmja] or [jiku:la] & [lki:f] \\
\hline New clothes & [Jədda] & [hatta] \\
\hline Lorries & [kmajən] & [kamju:na:t] \\
\hline
\end{tabular}

and 20 did not return it back. Henceforth, we will deal with 80 informants. As Table 2 shows.

As Table 2 demonstrates, the respondents were selected randomly depending on some social variables especially age and gender. In this sense, the first category comprises about (26) of the informants i.e., they represent (32, 5\%) and most of them are students, town hall workers and housewives... etc.

\subsection{Research Instruments}

Through applying many sociolinguistic methods including a questionnaire, an interview and participant observation, this study will explore the dialect used by Maghnia speech community. It will also investigate how other languages help in the creation of this type of dialect. Secondly, this research paper aims to examine how some socio-cultural factors of Moroccan speakers affect the dialect used by Maghnia speakers and result in the dawn of bootleggers' slanguage.

\subsection{Questionnaire Analysis}

1) In your point of view, does the geographical location of Maghnia play an important role in language differences between woman and man?

a) Yes.

b) No.

c) Comments.

From Table 3 and Figure 1, we may realise that the majority of participants, who represent $70 \%$ of the sample, were with the idea that the geographical location of Maghnia affects the use of language between both sexes. In contradiction, $30 \%$ of the informants maintained that language is always changing since teenagers prefer innovation in social interaction.

Hence, most of the participants observed that Maghnia is considered as an important area in the West of Algeria since it is located in the border with Morocco. In fact, in the last decades, most of the citizens support commercial contact with Moroccans through what is called the "dark market" such as the illegal exchange of fuel and other goods including drugs, clothes and food. This situation pushes men in Maghnia to develop a new vocabulary for language contact. Indeed, they even create specific slang in order to hide their contact such as [ãmbijãs] which refers to drugs. They added that, these people, who are unconscious about social relations and interaction between both sexes, impose their position in this society over women. In other words, females, in Maghnia, are viewed as powerless and useless. In fact, they stated that the place of women is at home and their main works are cooking, washing and looking after children. Moreover, some men consider woman just as a machine to give babies. In their point of view, woman goes out just twice in her whole life. The first is to her husband's home, whereas the second is to the cemetery.

2) Do men prefer using bootleggers' language in Maghnia? (Table 4)

a) Yes.

b) No.

c) Comments and suggestions.

This question aims at determining the attitudes of both sexes mainly men towards the use of bootleggers' language. About $83,75 \%$ of the participants declared that men use this language. In contrast, few of them, who represent 16, 25\%, declared that men do not use bootleggers' codes (Figure 2).

Yet, the majority of respondents justified their answers claiming that these codes are frequently used. They continued stating that the main factor which pushes them to practise this work is the lack of jobs and other social 
Table 2. Categories of the informants.

\begin{tabular}{ccc|}
\hline Age & Females & Males \\
\hline $18-25$ & 18 & 8 \\
$26-35$ & 14 & 11 \\
$36-45$ & 5 & 9 \\
$46-55$ & 1 & 9 \\
Above 56 & 2 & 3 \\
Total & 40 & 40 \\
\hline
\end{tabular}

Table 3. Language use and the geographical location of maghnia.

\begin{tabular}{ccc}
\hline Suggestions & Females & Males \\
\hline a & 26 & 30 \\
b & 14 & 10 \\
Total & 40 & 40 \\
\hline
\end{tabular}

Table 4. Bootleggers' language and men's attitudes.

\begin{tabular}{ccc}
\hline Suggestions & Females & Males \\
\hline a & 36 & 31 \\
b & 4 & 9 \\
Total & 40 & 40 \\
\hline
\end{tabular}

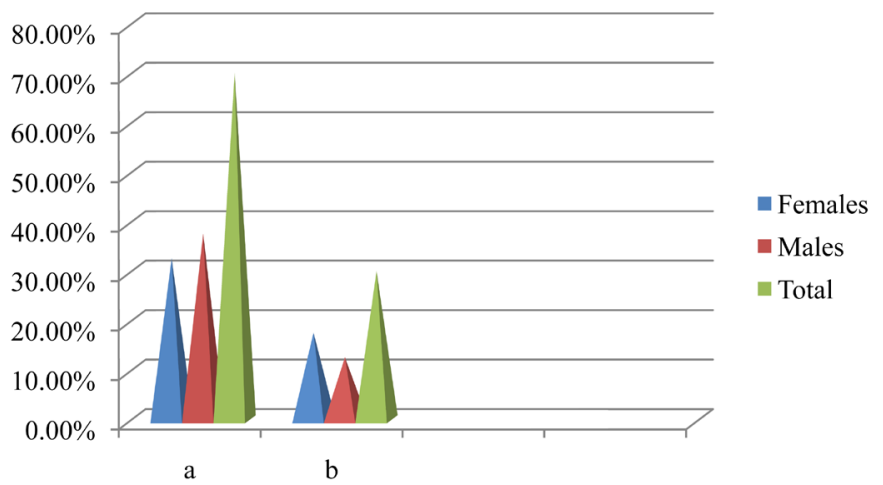

Figure 1. Language use and the geographical location of Maghnia.

problems. Among the expressions that they create, we have for instance, [tajwa:n], which is used to refer to a bad product. Other important examples include [sko:rti] or [berraj] which means the person who takes in charge to protect bootleggers from national security and border guardes. They even create expressions referring to cars

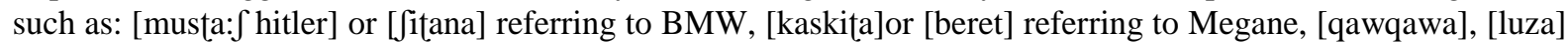
or[mbalga] referring to Mercedess... etc. Furthermore, they use special words to illegal cars that they do not contain legal papers for instance [muqatila]. On the other hand, females do not employ such vocabulary.

3) According to your point of view, why do most men prefer using bootleggers' language?

a) Because it is important in their work.

b) Because it is easy to communicate.

c) Because of the geographical location.

d) Comments.

Figure 3 and Table 5 clearly show the views of Maghnia speakers towards using bootleggers’ language. In 
fact, $51,25 \%$ declared that it is important in their work. In contrast, about $26,25 \%$ of them observe that the geographical location of Maghnia plays a crucial role in pushing them to learn this vocabulary, whereas few numbers, who represent $22,5 \%$, stated that it is used as a means of communication. Their comments were between the first and the last proposition. They supported their choice by justifying that since the educational level of Maghnia speakers is low, it obliges them to search for other substitutions to interact and communicate especially in their commercial domains. They feel the need for developing a coded language to exchange ideas and in order to avoid the understanding of national security.

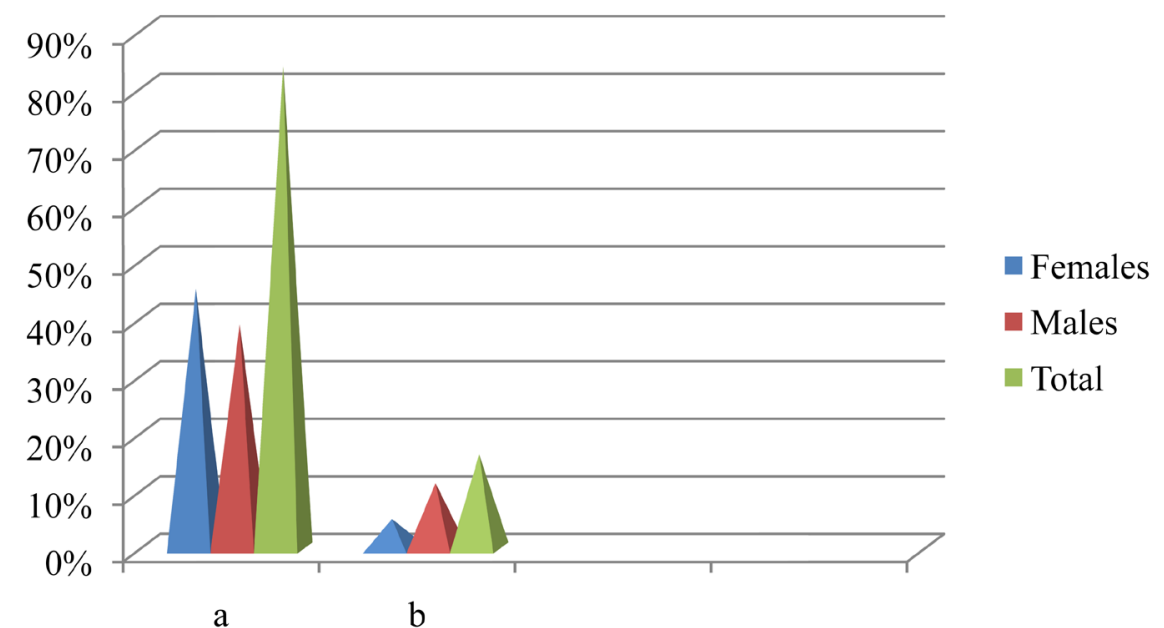

Figure 2. Bootleggers' language and men’s attitudes.

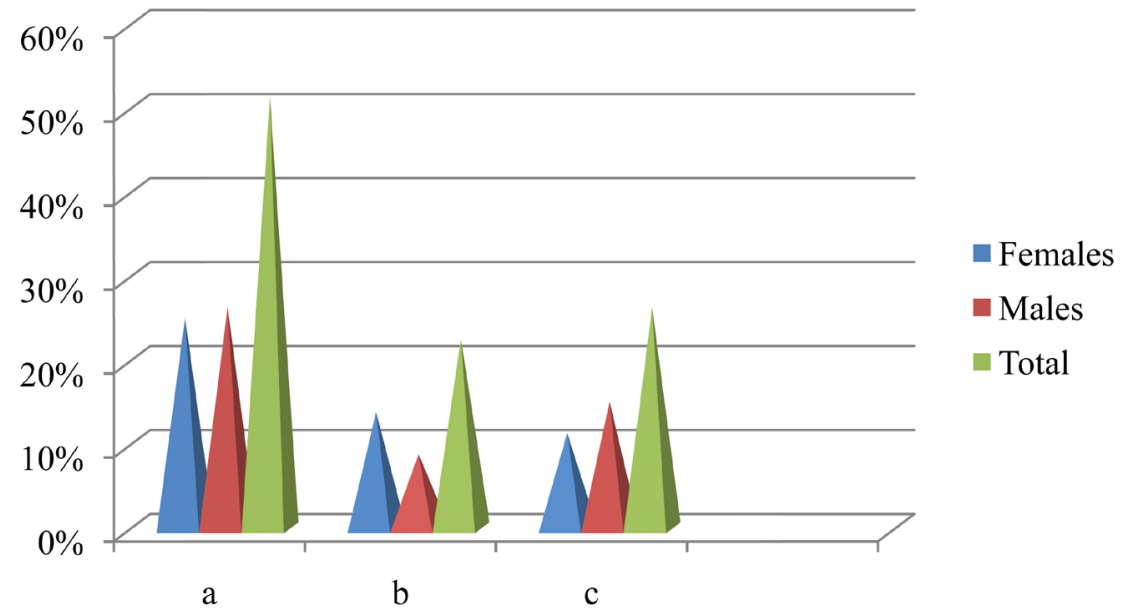

Figure 3. The main reasons for using bootleggers' language in Maghnia.

Table 5. The main reasons for using bootleggers' language in Maghnia.

\begin{tabular}{ccc}
\hline Suggestions & Females & Males \\
\hline a & 20 & 21 \\
b & 11 & 7 \\
c & 9 & 12 \\
\hline
\end{tabular}




\section{Conclusion}

From the foregoing discussions, it would be logical to argue that the results show that the socio-cultural structure of Maghnia speech community affects the identity of both genders. Therefore, it also influences their construction, use of sentences and expressions.

The most important results in this work are that Maghnia males differ largely in the words they use including terms referring to colours, clothes, cars and other objects. Besides, Maghnia males have created their own vocabulary which is a form of slang. In fact, this slang is the result of their illegal commercial contact with Moroccans since the majority of terms and expressions are in the form of codes. These codes are used as markers that identify those who are working as bootleggers. However, this vocabulary has been used by most males in Maghnia due to their contact with each other and because about $65 \%$ of people work as bootleggers.

Last and not the least, this research work offers a new explanation regarding how the socio-cultural structure of a given society is represented in their language and affects its structure in turn and results in the creation of new expressions. Another important result is that Maghnia speech community tries to create an appropriate atmosphere in order to realize successful social relations and this is the case of bootlegger's coded language.

\section{References}

Bassiouney, R. (2009). Arabic Sociolinguistics. Edinburgh University Press Ltd. http://dx.doi.org/10.3366/edinburgh/9780748623730.001.0001

Tannen, D. (1990). You Just Don't Understand: Women and Men in Conversation. New York: William Morrow. 